\title{
Studies on the male partners of couples presenting with infertility
}

\author{
Henry AMAH ${ }^{1 *}$, Confidence NWACHUKWU ${ }^{2}$, Ifeanyi OBIAJURU ${ }^{3}$ and \\ Catherine $\mathrm{AMAH}^{4}$ \\ ${ }^{1}$ Department of Microbiology Dept. of Medical Laboratory Science Rivers State University of Science \& \\ P.M.B 1010 Technology, P.M.B. 5080, Port Harcourt 08033972878,Imo State, Nigeria. \\ ${ }^{2}$ Dept. of Medical Laboratory Science, Rivers State University of Science \& Technology, P.M.B. 5080, Port \\ Harcourt, Nigeria. \\ ${ }^{3}$ Dept. of Medical Microbiology \& Parasitology, College of Medicine, Imo State University, Owerri, Nigeria. \\ ${ }^{4}$ Orange Specialist Laboratory, No. 10 Oparaugo Street, Owerri, Imo State, Nigeria. \\ *Corresponding author, E-mail: Hendoz1@yahoo.com; Tel: +234 08033972878
}

\begin{abstract}
A prospective study of 1000 males attending the infertility clinics of three tertiary health institutions was carried out, examining their spermogram, seminal fructose concentration and body mass index (BMI). The two groups (of 500 males partners each) examined were those of queried infertile by the clinicians and those of proven fertility (fertile men with time to pregnancy (TTP) $\leq 12$ months as reference group). Questionnaires and oral interviews were administered to the patients and subjects to reveal their occupational and medical histories, health conditions, working conditions, smoking habits and lifestyles. An inverse relationship between body mass index and the total number of sperm cells per subjects was observed. There was no relationship between the seminal fructose concentration and seminal activity. The mean percentage motility of spermatozoa was found to be statistically higher in fertile subjects $(87.15 \pm 4.66 \%)$ than in queried infertile subjects $(40.70 \pm$ $22.96 \%)$ at $\mathrm{P}<0.05$. The mean percentage sperm cell count was found to be statistically higher in fertile subjects $(71.74 \pm 15.22 \times 10$ cells $/ \mathrm{ml})$ than in queried infertile subjects $(23.68 \pm 21.07 \times 10 \mathrm{cell} / \mathrm{s} / \mathrm{ml})$ at $\mathrm{p}<0.05$. To ensure maximum fertility potential patients presenting with infertility may be advised to reduce body weight. (c) 2012 International Formulae Group. All rights reserved.
\end{abstract}

Keywords: Body mass index, seminal fructose, motility, sperm cell count, morphology.

\section{INTRODUCTION}

Infertility primarily refers to the state where the marriage of the couple has not yielded pregnancy after 12 months of contraception - free intercourse (Makar et al., 2002). In approximately one-third of these couples, a male factor appears to be singularly responsible, and in an additional $20 \%$ both a male and a female factor can be identified
(Gilbert et al., 1994). Possible causes of male infertility are low sperm court, age, overweight, underweight, genetic disorders, general diseases and infections. However, important issues related to the evaluation of male factor include the completion of a full medical history, physical examination and the proper interpretation of pertinent laboratory tests. Certainly, the cornerstone of evaluation 
will be the laboratory analysis of the semen (Makar et al., 2002). Although, various etiological factors produce changes in the seminal fluid, an estimation of the seminal fluid contents such as seminal fructose will be useful in investigating an infertile couple and as an index of male fertility. However fructose serves as the primary source of energy for ejaculated sperm in their aerobic environment and is a factor responsible for induction of sperm contact accessory sex organ secretions (Lipshultz and Howards, 1999). An increased male body mass index (BMI) is a risk factor of infertility. Hence, the alteration in the metabolic and hormonal state created by obesity has been suggested to affect the male reproductive potential (Hammoud et al., 2006). Finally, it has been shown that the longer a couple remains subfertile, the worse their chance for an effective cure.

\section{MATERIALS AND METHODS \\ Methods}

\section{Subjects/specimen and location sites}

This study was carried out in three cities in Nigeria viz: Owerri (federal medical centre, $\mathrm{O}$ and $\mathrm{G}$ unit), Port-Harcourt (fertility clinic of BMSH) and Nnewi (Nnamdi Azikiwe University teaching Hospital, $\mathrm{O}$ and $\mathrm{G}$ unit). The study was based on 1000 male subjects (age range 25-45 years) divided into two groups.

Group 1 (Test subjects): Group one consists of 500 patients attending investigation of an infertile marriage. They were queried infertile by the clinicians and from the information extracted from the questionnaires. Group 2 (control): Group two consists of 500 married males of proven fertility. The patients were asked to fill an elaborate questionnaire produced for the study.

\section{Specimen collection and delivery}

The subject collected the semen after a minimum of 48 hours and no longer than 7 days of sexual abstinence. The name of the man, period of abstinence, date and time of collection were properly recorded. The specimen was delivered to laboratory within 1 hour after collection. The specimen was obtained by masturbation and ejaculated into a clean wide-mouthed glass or plastic container. The container was slightly warned to minimize the risk of cold shock. Ordinary condoms were not allowed for semen collection. In cases in which masturbation is not possible or against an individual's values, the specimen was collected in a nonspermicidal condom following intercourse. Incomplete specimens were not analyzed, particularly where the first portion of the ejaculate is lost. For seminal fructose analysis, diabetics were excluded from the study.

\section{Macroscopic evaluation}

An initial macroscopic examination of semen specimen was performed after liquefaction within 60 minutes at warm temperature. The volume of the ejaculation was measured with a graduated Cylinder. The $\mathrm{pH}$ paper range of 6.1 to 10.0 was used to test the $\mathrm{pH}$. The consistency was estimated by introducing a glass rod into the sample and observing the thread that forms on withdrawal of the rod.

\section{Microscopic investigation}

The sperm concentration, motility and normal morphology were evaluated according to world Health organization (WHO, 1999).

\section{Motility}

A fixed volume of semen (not more than $10 \mu \mathrm{l})$ was delivered onto a clean glass slide and covered with a 22 x $22 \mathrm{~mm}$ coverslip. The motility was assessed microscopically, the percentage of motile cell being estimated from the total of 100 spermatozoa counted.

\section{Sperm concentration}

A well - mixed liquefied semen was diluted 1 in 20 with sodium bicarbonateformalin diluting fluid. An improved Neubauer ruled chamber was filled with well - mixed diluted semen and waited for 3-5 minutes for the spermatozoa to settle. The number of spermatozoa in an area of $2 \mathrm{sq} \mathrm{mm}$ 
(i.e. 2 large squares) was counted. The number of spermatozoa in $1 \mathrm{ml}$ of seminal fluid was calculated by multiplying the number counted by 100,000 .

\section{Normal morphology}

An aliquot (about $50 \mu \mathrm{l}$ ) of liquefied well -mixed semen was smeared on a slide. The semen was fixed with $25 \% \mathrm{v} / \mathrm{v}$ ethanol for 5-10 minutes and allowed to air-dry. The slide was stained with dilute carbol fuchsin for 3 minutes and counterstained with dilute Loeffler's methylene blue for 2 minutes, washed with water and air-dried. The percentage showing normal morphology was estimated by examining several fields using the 100x objective. The percentage of normal morphology was estimated from the total of 100 spermatozoa counted.

\section{Measurement of Body Mass Index (BMI)}

The height (meter) and weight (kilogram) of the subjects were measured and recorded on the day of semen collection. BMI was calculated for each subject by dividing the weight by the square of his height, and expressed in metric as kilogram / metre ${ }^{2}$. The subjects were grouped according to the published BMI ranges as follows, Normal weight, 18. $5-24.9 \mathrm{~kg} / \mathrm{m}^{2}$, Overweight, 25 .0- $29.9 \mathrm{~kg} / \mathrm{m}^{2}$ and obese; $30.0 \mathrm{~kg} / \mathrm{m}^{2}$ and above.

\section{Seminal fluid fructose estimation using acid resorcinol colorimetry (Mann, 1984)}

An aliquot $(0.1 \mathrm{ml})$ of seminal fluid was pipette into a centrifuge tube and mixed by shaking after $1.9 \mathrm{ml}$ of water was added.

Subsequently, $1 \mathrm{ml}$ of $\mathrm{Ba}(\mathrm{OH})_{2}$ and $\mathrm{ZnSO}_{4}$ each were added and properly mixed. It was centrifuged at $2000 \mathrm{rpm}$ for 30 minutes.

Thereafter, $1.0 \mathrm{ml}$ of both the supernatant and the standard were pipetted into separate test tubes and tested similarly. Then $1.0 \mathrm{ml}$ of resorcinol reagent and $3.0 \mathrm{ml}$ of $\mathrm{HCl}$ reagent were added separately and properly mixed. They were stood in a water bath for 8 minutes. Cooling was done at room temperature under the running water. It was read in a colorimeter at $520 \mathrm{~nm}$ using the blank (distilled water) to zero.

\section{RESULTS}

The sperm characteristics of queried infertile male were assessed under different body mass index (BMI) groups as shown in Table 1. It showed significant difference in sperm cell count among the BMI groups $(\mathrm{p}<0.05)$.There was no significant difference in the seminal volume and motility among the stated BMI groups $(\mathrm{P}>0.05)$. But in normal cell morphology, a significant difference was observed between the Overweight BMI and Obese BMI groups $(\mathrm{P}<0$.05). The mean sperm cell counts among the different body mass index (BMI) groups in the queried infertile males were represented in the pie chart (Figure 1).

Furthermore, the sperm characteristics of queried infertile males were assessed under 3 different fructose concentrations (groups) as shown in Table 2. Anova (least significant difference) revealed that there was no significant difference $(\mathrm{P}>0.05)$ in the sperm characteristics among the 3 different fructose concentration levels.

However, the sperm cell count, percentage motility of spermatozoa and percentage normal morphology of spermatozoa were measured in the seminal fluid of 500 fertile and 500 queried infertile males in Nigeria. From the Table 3, the mean percentage motility of spermatozoa was found to be statistically higher in fertile subjects $(87.15 \pm 4.66 \%)$ than in infertile subjects $(40.72 \pm 22.96 \%) ; p<0.05$. As Shown in the Table 4, the mean sperm cell count was found to be statistically higher in fertile subjects ( 71 . $94 \pm 15.22 \times 10^{6}$ cells $/ \mathrm{ml}$ ) than in queried infertile subjects $\left(23.68 \pm 21.07 \times 10^{6}\right.$ cell $/ \mathrm{ml}$; $\mathrm{P}<0.05$. Also, the mean percentage normal morphology of spermatozoa was found to be statistically higher in the queried infertile subjects $(88.45 \pm 4.55 \%)$ than in the queried infertile subjects $(70.65 \pm 25.61 \%)$ as shown in the Table 5. 
Table 1: Male sperm characteristics of queried infertile male under different Body Mass Index (BMI).

\begin{tabular}{lcccc}
\hline $\begin{array}{l}\text { Body Mass Index } \\
\text { (BMI) }\end{array}$ & Motility & $\begin{array}{c}\text { Sperm Cell } \\
\text { Count }\end{array}$ & $\begin{array}{c}\text { Normal } \\
\text { Morphology }\end{array}$ & Volume \\
\hline Normal & $44.67^{\mathrm{a}}$ & $36.30^{\mathrm{a}}$ & $73.07^{\mathrm{a}}$ & $3.10^{\mathrm{a}}$ \\
Overweight & $38.10^{\mathrm{a}}$ & $19.37^{\mathrm{b}}$ & $73.70^{\mathrm{a}}$ & $3.37^{\mathrm{a}}$ \\
Obese & $41.20^{\mathrm{a}}$ & $12.20^{\mathrm{c}}$ & $55.50^{\mathrm{b}}$ & $3.20^{\mathrm{a}}$ \\
\hline
\end{tabular}

Means in the same column with the same letter are not significantly different at $\mathrm{P}<0.05$, according to last significant difference (LSD).

Table 2: Means sperm characteristics of queried infertile males under different fructose concentration (Levels) groups.

\begin{tabular}{lcccc}
\hline $\begin{array}{l}\text { Fructose } \\
\text { Concentration Group }\end{array}$ & Motility & $\begin{array}{c}\text { Sperm Cell } \\
\text { Count }\end{array}$ & $\begin{array}{c}\text { Normal } \\
\text { Morphology }\end{array}$ & Volume \\
\hline A & $25.00^{\mathrm{b}}$ & $14.90^{\mathrm{b}}$ & $36.00^{\mathrm{b}}$ & $3.70^{\mathrm{a}}$ \\
$\mathrm{B}$ & $41.23^{\mathrm{a}}$ & $23.87^{\mathrm{a}}$ & $78.37^{\mathrm{a}}$ & $3.27^{\mathrm{a}}$ \\
$\mathrm{C}$ & $43.67^{\mathrm{a}}$ & $25.34^{\mathrm{a}}$ & $76.73^{\mathrm{a}}$ & $3.40^{\mathrm{a}}$ \\
\hline A: 0 to $100 \mathrm{mg} / \mathrm{dl}, \mathrm{B}: 101$ to $200 \mathrm{mg} / \mathrm{dl}, \mathrm{C}: 201$ to $300 \mathrm{mg} / \mathrm{dll}$ Means in the same column with the same letter are not \\
significantly different at P $\leq 0.05$, according to least significant different (LSD).
\end{tabular}

Table 3: Comparison of percentage sperm motility in fertile and queried infertile males.

\begin{tabular}{lccc}
\hline & Fertile & Queried infertile & P-value \\
\hline No. of subjects & 500 & 500 & \\
Mean sperm motility (\%) & $87.1 \pm 4.66$ & $40.72 \pm 22.96$ & $\mathrm{P}<0.05$ \\
Range & $75.0-95.0$ & $05.0-80.0$ & \\
\hline
\end{tabular}

Table 4: comparison of mean percentage sperm cell count in fertile and queried infertile males.

\begin{tabular}{lccc}
\hline & Fertile & Queried Infertile & P - value \\
\hline No. of subjects & 500 & 500 & \\
Mean cell x $10^{6}$ cell $/ \mathrm{ml}$ & $71.94 \pm 15.22$ & $23.68 \pm 21.07$ & $\mathrm{P}<0.05$ \\
Range & $38.0-114.0$ & $0.0-70.0$ & \\
\hline
\end{tabular}


Table 5: comparison of mean percentage sperm cell morphology in fertile and queried infertile males.

\begin{tabular}{lccc}
\hline & Fertile & Queried infertile & P-value \\
\hline No. of subjects & 500 & 500 & \\
Mean sperm motility (\%) & $88.45 \pm 4.55$ & $70.65 \pm 25.61$ & $\mathrm{P}<0.05$ \\
Range & $80.0-96.0$ & $45.0-95.0$ & \\
\hline
\end{tabular}

$(28.5 \%)$

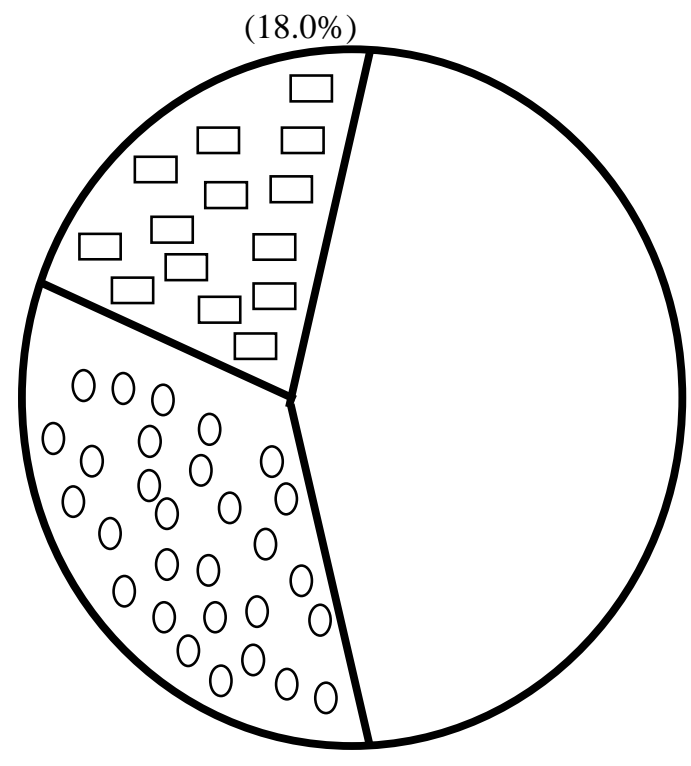

$(53.5 \%)$

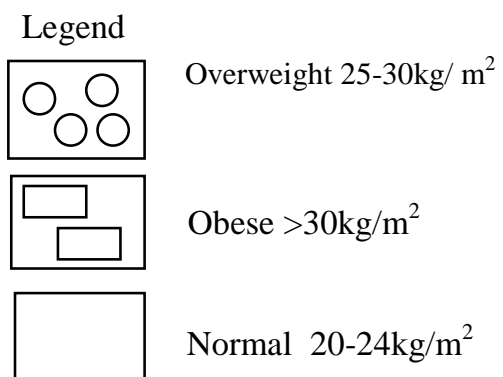

Figure 1: Means Sperm cell counts among the Different Body Mass Index Groups in the queried infertile males.

\section{DISCUSSION}

The inverse relationship between body index (BMI) and the total number of sperm cell per subject were observed. This does not fully agree with Hilton et al. (2006) which observed an inverse relationship between BMI and the total number of normal - motile cell per subject. It was observed that men with a MBI greater than $25 \mathrm{~kg} / \mathrm{m}^{2}$ have fewer sperm cells per ejaculate. It was found that for every three-point increase in a man's BMI, couples have $10 \%$ more likely to be infertile (Sallmen, 2006).

Biologically, fat secretes a hormone called aromatase, which converts the hormone testosterone to the hormone estrogen. Testosterone is critical for sperm production and estrogen depresses sperm production and may lead to a low sperm count in obese men. Also excess fat in the thighs of obese men may boast the temperature inside the scrotum and sperm production could be hundred (Riley and Masters, 2006). Nevertheless, patients 
presenting with excess suprapubic fat have poor semen quality, due to altered sperm production (Berman et al., 1996). The alteration in the metabolic and hormonal state created by obesity has been suggested to affect the male reproductive potential (Hammoud et al., 2006). The mean seminal fructose concentration in fertile males $(203.93 \pm 32.36 \mathrm{mg} / 100 \mathrm{ml})$ obtained in the study is similar to that reported elsewhere on caucasians by Moon and Bunge (1997), who obtained a mean value of $222 \mathrm{mg} / 100 \mathrm{ml}$. This implied that race has no recognized influence upon blood glucose level. There was no significant difference of seminal fructose concentration between fertile and queried infertile males and also between oligospermic and azoospermic subjects. This is similar to results obtained by Andrade - Rocha, (1999). This could be attributed to the fact that once there is some degree of testosterone production from the leydig cells, the seminal vesicles will maintain a normal production of fructose and circulating levels of testosterone have been found to be normal in most infertile men (Olsen et al., 1995). Hence, the main role of assessment of seminal fructose lies in identifying patients with seminal vesicle dysfunction. There were insignificant differences in mean ejaculate volume between fertile and queried infertile males as well as between azoospermic and oligospermic subjects. These could be attributed to the fact that the major bulk of semen is composed of secretions from the male sex accessory gland which are under the control of testosterone. And testosterone has been found to be normal in most infertile males. The mean sperm count in fertile Nigerian males $\left(71.94 \pm 15.22 \times 10^{6}\right.$ cell $/ \mathrm{ml}$ ) obtained in this study is in agreement with the findings of Onwuameze et al. (1987). The total number of spermatozoa per ejaculate reflects spermatogenesis and is related to the duration of sexual abstinence. The spermatozoal motility and morphology in fertile subjects were significantly higher than that obtained in the queried infertile subjects which are in an agreement with that of Ladipo et al. (1978).

Physical sperm aberrations occurring during the production of sperm and the storage in the epididymis may be due to genetic syndromes and varicoceles. Importantly seminal tract infection may affect fertility by damaging the sperm and hampering their motility.

\section{REFERENCES}

Andrade-Rocha FT. 1999. Seminal fructose levels in male infertility: Relationship with sperm characteristics. International Urology and Nephrology, 31(1): 107-111.

Berman NG, Wang C, Paulsen CA. 1996. Methodological issues in the analysis of human sperm Concentration data. Journal of Andrology, 17: 68-73.

Gilbert BR, Schlegel PN, Goldstein M. 1994. Office evaluation of the infertile males. AUA Update Series, 13: 70-75.

Hammoud A, Gibson C. 2006 . Obesity and male reproductive potential. Journal of Andrology, 4:15-18.

Hilton I, Joe M, Carlene E, Daniel S, Michael W. 2006. Impact of body mass index values on sperm quality and quantity. Journal of Andrology, 27: 450-452.

Ladipo OA, Olatunbosun DA, OJO OA. 1978. Biophysical and Biochemical analysis of semen in Fertile and infertile Nigeria males. International Journal of Gynaecology and Obstetrics, 16: 58-60.

Lipshultz LI, Howard SS. 1999. Infertility in the Male $\left(2^{\text {nd }}\right.$ edn). C. V. Mosby: Baltimore, London, Philadelphia; 45210.

Makar RS, Toth TL, 2002. The Evaluation Of infertility. American Journal of Clinical Pathology, 117: 95-103.

Moon KH, Bunge RG. 1997. Seminal fructose as an indicator of androgenic activity. 
Critical Analysis of Investigative Urology, 8(4): 373-376.

Olsen GW, Bonder KM, Rambow JM, Ross CE, Lipshultz LI. 1995. Have sperm counts been reduced 50 percent in 50 years? A statistical model revisited. Fertility and Sterility, 63: 887 -893.

Onwuameze IC, Mbonu 0, Udeozo IO, Ojukwu JC, Okonkwo PO. 1987. Hypophyseal Hormones in Nigerian males. West African Journal of Pharmacology and Drug Research, 7(1): 51-57.
Riley FJ, Masters WH. 2006. Problem of male Fertility. Bacteriology of Human semen. Fertility and Sterility, 7: 128-132.

Sallmen M. 2006. Connection Between Body Mass Index and Fertility. Web MD Medical News.

World Health Organization. 1999. WHO Laboratory Manual for the Examination of Human Semen and SpermCervical Mucus Interaction. Cambridge University Press: London; 42 -49. 